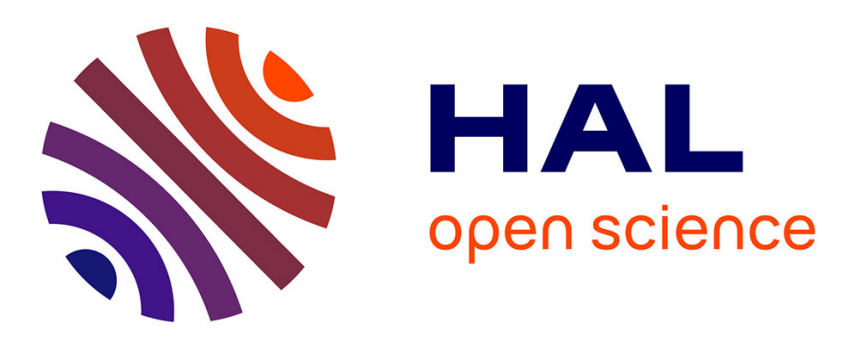

\title{
Shadow Economy And Unemployment Rate In U.S.A. Is There A Structural Relationship? An Empirical Analysis.
} Roberto Dell'Anno, Offiong Helen Solomon

\section{- To cite this version:}

Roberto Dell'Anno, Offiong Helen Solomon. Shadow Economy And Unemployment Rate In U.S.A. Is There A Structural Relationship? An Empirical Analysis.. Applied Economics, 2008, 40 (19), pp.2537-2555. 10.1080/00036840600970195 . hal-00582021

\section{HAL Id: hal-00582021 https://hal.science/hal-00582021}

Submitted on 1 Apr 2011

HAL is a multi-disciplinary open access archive for the deposit and dissemination of scientific research documents, whether they are published or not. The documents may come from teaching and research institutions in France or abroad, or from public or private research centers.
L'archive ouverte pluridisciplinaire HAL, est destinée au dépôt et à la diffusion de documents scientifiques de niveau recherche, publiés ou non, émanant des établissements d'enseignement et de recherche français ou étrangers, des laboratoires publics ou privés. 


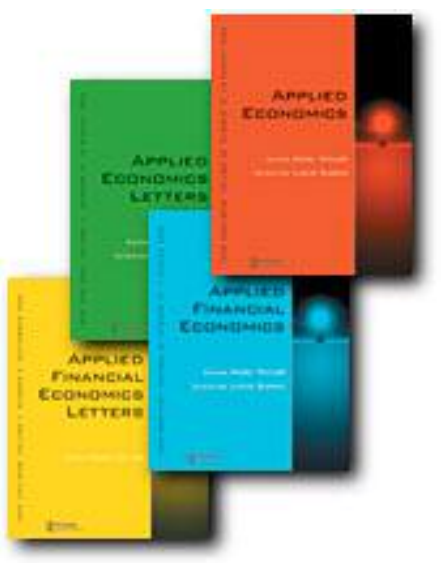

Shadow Economy And Unemployment Rate In U.S.A. Is There A Structural Relationship? An Empirical Analysis.

\begin{tabular}{|r|l|}
\hline Journal: & Applied Economics \\
\hline Manuscript ID: & APE-05-0660.R1 \\
\hline Journal Selection: & Applied Economics \\
\hline JEL Code: & $\begin{array}{l}\text { E26 - Informal Economy /Underground Economy < E2 - } \\
\text { E - Macroeconomics and Monetary Economics, O17 - Formal, } \\
\text { Informal Sectors; Shadow Economy, etc. < O1 - Economic } \\
\text { Development < O - Economic Development, Technological Change, } \\
\text { and Growth }\end{array}$ \\
\hline Keywords: & Shadow Economy, MIMIC Model, Okun's law \\
\hline \multicolumn{2}{|l}{} \\
\hline
\end{tabular}

powersd by ScholarOne

Manuscript Central ${ }^{\text {H }}$ 


\begin{abstract}
This paper aims to estimate the size of the U.S. shadow economy (SE) using a Structural Equation Approach and to evaluate if a structural relationship exists between the SE and the unemployment rate (UR) in the United States. The size of the SE is estimated to be decreasing over the last two decades. We corroborate the existence of a structural relationship between the shadow economy and the unemployment rate by using a simple theoretical model. Furthermore, we extend the Okun's law to estimate the structural relationship between growth rate of official GDP, SE and UR. Our results indicate a significant positive relationship between the SE and the $U R$.
\end{abstract}

\title{
1. Introduction
}

The shadow economy (SE) is of great importance for the economy because it has relevant repercussions on the many aspects of economic and social life of a country.

This paper aims to estimate the size of the U.S. shadow economy (SE) and to evaluate if a structural relationship exists between the SE and the unemployment rate (UR) in the United States.

First, we estimate the size of the shadow economy using the multiple indicator multiple cause model (MIMC). Secondly, a simple theoretical model is used to argue the existence of a structural relationship between the SE and UR. Finally, the structural relationship between the shadow economy and the unemployment rate is demonstrated empirically by re-examining the Okun's law. Empirical evidence has shown that a consequence of high unemployment is the growth of the shadow economy (Enste, 2003). As a result it has been argued that the labour force participation rate is an indicator for the growth of the shadow because a growing SE is reflected by a reduction of the number of workers who work in the official economy.

A growing SE presents problems for the implementation of government policy. For example, there is the potential for huge fraud on the social welfare system as people who claim to be unemployed while working in the SE claim unemployment benefits. Another important feature is that workers and producers in the SE do not pay tax but free ride on public services. As a result this reduces the quantity and quality of the public provision of goods and services for workers and 
producers who pay tax. On the other hand, it is our opinion that the shadow economy benefits the economy because it absorbs the unemployed from the official economy. As a result, the SE reduces the effect of unemployment rate on the official economy. Hence, our motivation for this paper is to test if a structural relationship exists between the SE and the UR by using Okun's law. This is because the Okun's law provides empirical evidence of an inverse relationship between output growth and a decrease in unemployment. Our economic intuition is that the higher the rate at which workers lose jobs in the formal sector, the higher the unemployment rate. The higher the unemployment rate, the higher the shadow economy as workers choose to work in the SE rather than remain unemployed. Thus, we hypothesize that the presence of the SE reduces the effect of unemployment on the official economy.

This paper is organised into six sections. Section 2 provides an overview of related literature on the definition, causes and indicators of the SE. It also draws from the literature, the evidence supporting the connection between the SE and UR. Section 3 describes how the SE is estimated using the Multiple Indicators Multiple Causes Model (MIMIC). Section 3.A describes the data used in the estimation. The results of the estimated coefficients of the MIMIC model are then discussed in Section 3.B. This is followed by a description of how a time series of the U.S. shadow economy is obtained in sub-section 3.B.1. Section 4, presents a simple theoretical model to show the existence of a structural relationship between the SE and the UR. In Section 5, we reexamine the Okun's law by introducing the SE into the relationship between unemployment rate and growth rate of output. The results of our OLS regressions suggest the presence of a structural relationship between the growth of the SE and the UR in the U.S. Section 6 is the conclusion.

\section{An overview on the Shadow Economy and its relationship to Unemployment}

In this section, we provide an overview on the shadow economy. The SE is discussed in terms of its definition, classification of its activities as well as causes and indicators. We also discuss the connection between the SE and the UR. 


\section{A What Shadow Economy Measures?}

The SE has been characterized with confusion with regard to it's meaning. Each definition draws out a different set of attributes that describe it. The shadow economy is also referred to as underground, informal, hidden, parallel, clandestine, second, irregular or household economy. The confusion appears to originate from the work of different fields (economics, sociology, statistics, law etc.) who define the SE based on the key "criteria" contributing to its development. Hence, there is no precise definition. Gërxhani (1999) provides a variety of definitions for the SE based on political, economic and sociological classifications. In this paper we focus on the economic definition of the SE, it can be classified into two categories. These are "labour-oriented" and "sizeoriented" definitions.

The "labour-oriented" definitions focus on the impact of the SE on the labour market. The shadow economy is defined as the sum total of all income-earning activities excluding contract and legal employment. The labour force that emerges within this economy arises from tax and/or social security evasion.

The "size-oriented" definition considers the relationship between state regulation and the operation of a business. Swaminathan (1991) defines the SE as "establishments which are unregistered and unlicensed". It also considers the distortions that the SE causes to national accounts. Feige (1981) defines the SE as "all economic activities, which because of accounting conventions, non-reporting or under-reporting, escape social measurement apparatus, most notable the GNP accounts". This paper follows the size oriented classification and defines the SE as that part of the economy that operates outside the purview of government regulation.

It is because of this myriad of definitions that the System of National Accounts (SNA) introduced an aggregate called the "Non-Observed Economy" or NOE. As a result, the Italian National Statistical Institute (ISTAT) classified the NOE as shown in the flowchart in figure 1.

The NOE comprises all product activities that can be classified into the following three areas OECD (2002): Underground production (T1, T2, T3, T4, T5); Informal production (T6); Illegal production (T7). 
Figure 1: ISTAT Framework of Non-Observed Economy

Underground production represents the area of production activities that are not directly observed can be broadly sub-divided into two. The underground economy can be broadly subdivided into two: (a) Economic (T4, T5). These are activities carried out outside government regulations such as avoiding tax, minimum wages, number of work hours, working conditions for labourers. (b) Statistical (T1, T2, T3). These are production activities not registered due to failure to fill statistical questionnaires. Their activities go undetected using traditional survey methods due to the small nature of the enterprise.

Informal production (T6) refers to productive institutional units characterised by: (a) A low level of organisation; (b) Little or no division between work and capital; (c) Work relations based on occasional jobs, kinship, or personal relations. This context comprises the activity of craftsmen, peddlers without licences, farm workers, home workers, and unregistered activities of small merchants.

Illegal production (T7) includes the activities oriented at the production of goods and services whose sale, distribution or possession is prohibited by law. Included in this area are also productive activities carried out by unauthorised operators ${ }^{1}$. Due to the difficulty in estimation, that could limit international comparability, the illegal activities are often excluded by the national accounts.

In this research, we consider the SE as the part of NOE caused by economic reasons (T4, T5, T6).

\footnotetext{
${ }^{1}$ The 1993 SNA states explicitly that illegal activities should be included in the SNA, noting that "despite the obvious practical difficulties in obtaining data on illegal production, it is included within the production boundary of the System" (1993, SNA 6.30), and that: "All illegal actions that fit the characteristics of transactions - notably the characteristic that there is mutual agreement between the parties - are treated the same way as legal actions" (1993, SNA 3.54). The 1993 SNA suggests that illegal actions for which there is no mutual agreement can be construed as an extreme form of externality for which, in general, no values are imputed in the national accounts. So it is absence of consent rather than illegality that is actually the criterion for exclusion from the production boundary. $\operatorname{OECD}(2002, \mathrm{p} .38)$.
} 


\section{B Causes of the Shadow Economy}

Empirical studies and theoretical models using data drawn from several countries conclude that in general the key factors that cause the growth of the SE are: taxes and social security contributions (SSC), composition of the labour force (e.g. unemployment and self-employment rate) and the quality of governance.

The burden of taxation is a major cause for the increase in the SE. The higher the tax rate, the greater the difference between the cost of labour in the formal economy and the after-tax earnings from work. As a result, higher taxes increase the supply of labour in the SE. This difference can be very large. For example in Germany and Austria, the difference between pre-tax earnings and post-tax earnings can be as much as a workers wages. As this difference depends on SSC and the overall burden of taxation, these are important factors that cause the increase in the SE. Johnson et al. (1998a, 1998b) find that taxes have a significant impact on the SE. Other studies opine that the marginal tax rate increases the substitution effect of the labour-leisure choice in favour of a greater increase in the supply of labour in the SE. In the U.S, a 1 percentage point increase in the marginal federal personal income tax increases the shadow economy by 1.4 percentage points (Cebula, 1997).

We consider the structure of labour force as crucial factor that affects the SE. In particular, we take into account the UR and the number of self-employed as a percentage of the labour force. For the UR we refer to the paragraph 2.B.1. About the self-employment rate according to Bordignon and Zanardi (1997) such workers have greater possibilities for tax evasion. They usually have a greater number of deductible expenses, both from their taxable base and their tax bill in personal income tax. As they work very closely with their clients they can collude with them in the evasion of indirect taxes. Additionally, they find it easier than bigger firms to employ irregular workers since they have fewer internal and external auditing controls. Therefore, ceteris paribus, a high rate of self-employment means a large SE.

Quality of governance, bureaucracy, government regulations, such as rigid labour laws can lead to a huge increase in the cost of labour in the SE. These costs can be shifted to the employees providing an additional incentive to work in the SE. This observation has been supported by 
various empirical studies such as Johnson et al. (1997). A one-point rise (ranging from 1-5) in the regulation index causes an 8.1 percent increase in the shadow economy.

Friedman et al. (2000) in an exhaustive study find a significant positive correlation between every existing measure of regulation and the SE. They also show that for seventy-six countries, a one-point increase in the regulation index (ranging from 1-5) leads to a $10 \%$ increase in the proportion of the shadow economy relative to the formal economy.

A country characterised by strong governance has a smaller shadow economy. This relationship was presented in a simple model by Johnson et al. $(1998 \mathrm{a}, \mathrm{b})$ in which countries with higher tax revenues were associated with fewer regulations and less corruption. As a result, they had smaller shadow economies. Consequently, there is a "good equilibrium" characterized by reduced taxes, low government regulations, low levels of corruption, large tax revenues and a strong rule of law. On the other-hand, there is the "bad equilibrium" characterised by high taxes, rigid government regulations, high incidence of corruption, declining tax revenues and a weak enforcement of the law.

\section{B.1 Overview of the relationship between the Shadow Economy and Unemployment}

From the foregoing, people work in the SE because of the increased cost that firms in the formal sector have to pay to hire a worker. The increased cost comes from the tax burden and government regulations on economic activities. Schneider and Enste (2000) explain that the individual decision to work in the SE is the reaction to being overburdened by tax and state regulations and so they choose the "exit option" rather than the "voice option" ${ }^{2}$.

For instance it is well known that in the OECD countries, unemployment is caused largely by high labour costs. In discussing the growth of the shadow economy, the empirical evidence suggests two important factors: (a) reduction in official working hours, (b) the influence of the unemployment rate.

In an effort to reduce the unemployment rate, France and Germany reduced the quantity of working hours because of the limited amount of work "and that this quantity has to be

\footnotetext{
${ }^{2}$ Individual choose to exit the formal sector to work or operate business in the SE rather than choose to vote against the government in an election.
} 
redistributed". But Enste (2003) points out that this idea "neglects" the fact that reducing the number of hours of work below worker's preferences raises the quantity of hours worked in the SE. This increases the growth of the shadow economy. Early retirement also increases the quantity of hours worked in the SE.

De Gijbel (1984) and Riebel (1983, 1984) explain that part-time work offers an excellent opportunity to work in an untaxed and unregulated economy. Lemieux et al. (1994) using micro data from a survey conducted in Quebec city (Canada) provide extensive research on the supply of labour in the underground economy. Their key results show that "participation rates and hours worked in the underground sector also tend to be inversely related to the number of hours worked in the regular sector". Empirically, there is a huge negative elasticity of substitution between the hours worked in the SE and the wage rate in the regular sector. They also show that there is a high mobility between the sectors.

In Schneider and Enste (2000, p.108) are reported the size of the labour force in the official and shadow economies in some OECD countries. In France the size of the shadow labour force increased from between $3 \%-6 \%$ in $1975-1982$ to between $6 \%-12 \%$ in $1997-1998$. This was followed by an increase in the size of the SE from $6.9 \%$ to $14.9 \%$ within the same period. In Germany, between 1974-1982 the shadow labour force was around $8 \%-12 \%$. However this increased to around 19\%-23\% between 1997-1998. The increase may provide a reason for persistent unemployment in Germany as the SE also increased from $10.6 \%$ to $14.7 \%$. In Spain the size of the shadow labour force increased from between $9.6 \%-26.5 \%$ in $1979-1980$ to between $11.5 \%-32.3 \%$ in $1997-1998$. This was followed by an increase in the size of the SE from $19 \%$ to $23.1 \%$ within the same years ${ }^{3}$. Also in Italy, there is an increase in the size of the shadow labour force from between $20 \%-35 \%$ to $30 \%-48 \%$ as the SE also rises from $16.7 \%$ to $27.3 \%$ within the same time period ${ }^{4}$.

In Italy, Bertola and Garibaldi (2003) present the case that an increase in payroll taxation can have effect on the supply of labour and the size of the shadow economy. An increase in tax and

\footnotetext{
${ }^{3}$ A detailed analysis of the Spanish shadow economy is presented in Ahn and De La Rica (1997), Alañón and Gómez-Antonio (2005).

${ }^{4}$ For an analysis of Italian shadow economy and its causes, see Dell'Anno and Schneider (2003).
} 
social security burdens not only reduces official employment but tends to increase the shadow labour force. This is because an increase in payroll tax can influence the decision to participate in official employment (Garibaldi and Wasmer, 2001). Also, Boeri and Garibaldi (2002) show between 1995-1999 a strong positive correlation between average unemployment rate and average shadow employment across 20 Italian regions.

On the contrary, Giles and Tedds (2002) argue that the effect of unemployment on the SE is ambiguous (i.e. both positive and negative). An increase in the number of unemployed increases the number of people who work in the black economy because they have more time. On the other hand, an increase in unemployment implies a decrease in the SE. This is because the unemployment is negatively related to the growth of the official economy (Okun's law) and the shadow economy tends to rise with the growth of the official economy. This ambiguous relationship is also mentioned by Tanzi (1999) as the class of labourers that compose the "shadow labour force" are extremely heterogonous. These include the officially "unemployed" to retired people, housewives and minors as well as those workers who work both in the official and shadow labour force.

\section{C Indicators of the Shadow Economy}

A growing SE has an impact on the formal sector through its effect on the product, money and labour markets. These factors are able to capture the changes in the size of the SE relative to the formal economy. We include in MIMIC model monetary indicators $\left(Y_{l}\right)$ (we use the ratio of narrow money to broad money), production in the formal economy $\left(Y_{2}\right)$ (measured by the Real Gross Domestic Product) and the labour force participation rates $\left(Y_{3}\right)$.

In terms of monetary indicators, most transactions in the SE occur cash. Therefore an increase in the SE, increases the demand for cash. In this paper, this is measured using the ratio of narrow money to broad money.

In terms of the labour force, an increase in the relative size of the SE is usually reflected by a reduction in official labour force participation rates. As more people work in the SE, the 
number of people who work in the formal economy declines. Also there is also a reduction in the number of hours spent working in the formal economy.

In the product market, a growing shadow economy encourages the flow of inputs out of the formal sector which can depress productivity in the formal sector as measured by the official growth rate.

An increase in production in the SE can be reflected by a decrease in the official growth rate in the formal economy. This is because during a recession, inputs such as labour and capital are moved out from the formal economy into the SE. Thus, there is an inverse relationship between the shadow economy and the formal economy. On the other hand, some argue that formal economy drives growth in the SE. This occurs in economies where there are significant linkages between the formal economy and shadow economy. In Nigeria, Arimah (2001) describes the presence of forward linkages in which certain aspects of production in the formal economy are subcontracted to the SE. Thus an increase in official growth rate increases the relative size of the SE as a result of increased demand for goods and services by firms in the formal economy. Thus, a recession could lead to a reduction in the growth of the SE owing to a reduction in the growth of the official economy. As a result, there is a direct relationship between the size of the SE and the growth of the official economy.

About the relationship between SE and official GDP, Schneider and Klingmair (2004) find evidence for different signs of correlations between them, according with the degree of economic development. They find a pro-cyclical relationship between activity in the legitimate and underground economy for developed countries but countercyclical for developing economies.

Although several comparative and single country studies have unearthed significant information, they have not been able to provide unambiguous results on the relationship between official to unofficial economy ${ }^{5}$.

\footnotetext{
${ }^{5}$ For an overview on the relationship between official and unofficial economy see also Dell'Anno (2003, 2007), Giles et al. (2002).
} 


\section{Modelling the Shadow Economy}

In this section, we show how the SE is modelled. We model the U.S. shadow economy using the MIMIC model developed by Jöreskog and Goldberger (1975). Using the standard LISREL notation of Jöreskog and Sörbom (1993), equation 1 is a measurement equation where $\eta_{t}$ (unobserved or latent) variable determines $y^{\prime}=\left(y_{1}, y_{2}, \ldots, y_{d}\right)^{\prime}$ column vector of indicators subject to a random error term $\varepsilon_{t} . \eta_{t}$ is an unobserved or latent and is a scalar. $\Lambda$ is a $(d \times 1)$ column vector of parameters that relates $y_{t}$ to $\eta_{t}$.

$$
y_{t}=\lambda \eta_{t}+\varepsilon_{t}
$$

Equation 2 is a structural equation which shows that the unobserved variable $\eta_{t}$ is determined by $x_{t}$ set of exogenous causes $\left(x_{1}, x_{2}, \ldots, x_{c}\right)$ and $\zeta_{t}$ a structural disturbance error term. $\gamma$ is a $(1 \times c)$ vector of structural parameters:

$$
\eta_{t}=\gamma x_{t}+\zeta_{t}
$$

Without loss of generality, all variables are taken to have zero expectations. From equations (1) and (2) it is assumed that:

(a) the elements of $\zeta_{t}$ and $\varepsilon_{t}$ are n.i.i.d and uncorrelated;

(b) the variance of the structural disturbance term $\zeta_{t}$ is $\Psi$;

(c) the covariance matrix of the measurement errors is a diagonal covariance matrix $\Theta_{\varepsilon}$.

Substituting equation 1 and 2 yields a reduced form solution which expresses a relationship between the observed variables $x_{t}$ and $y_{t}$. This is shown in equation 3 :

$$
y_{t}=\Pi^{\prime} x_{t}+z_{t}
$$

where:

- $\Pi=\lambda \gamma^{\prime}$ : is a $c \times d$ reduced form coefficients matrix and has rank one expressed in terms of $c$ and $d$ elements of $\lambda$ and $\gamma$;

- $z_{t}=\lambda \zeta_{t}+\varepsilon_{t}:$ is a reduced form disturbance vector; 
- $z$ has an $d \times d$ reduced form covariance matrix $(\omega)$ given by

$$
\omega=\lambda \varphi \lambda^{\prime}+\Theta_{\varepsilon}
$$

where: $\varphi=\operatorname{var}(\lambda)$ and $\Theta_{\varepsilon}=$ the reduced-form covariance matrix of the measurement errors.

The reduced form equation matrix has two restrictions. These are that the $c \times d$ coefficient matrix $\Pi$ has rank one and that $\Theta_{\varepsilon}$ is the sum of a rank one matrix and a diagonal $d \times d$ matrix. The necessary condition for identification is that the number of structural parameters should be equal to the number of reduced form parameters. From equations 1 and 2, our structural model has $c$ elements in $\gamma$, an element in the variance of $\zeta_{t}, \frac{c(c+1)}{2}$ elements in the variance of $x_{t}$ and $d$ elements contained in $\lambda$ and in the variance of $\varepsilon_{t}$. From equation 3 and 4 , the reduced form model contains $c d$ elements in $\Pi, \frac{d(d+1)}{2}$ elements in $\Theta_{\varepsilon}$ and $\frac{c(c+1)}{2}$ elements contained in the variance of $x_{t}$. An observation of the reduced form parameters shows that unique solutions to the structural parameters $\lambda$ and $\gamma$ cannot be obtained from the reduced form model. This is because altering the scale of $\eta$ yields an infinite number of solutions to $\lambda$ and $\gamma$ from the same reduced form solution. This inability to obtain unique solutions to $\lambda$ and $\gamma$ causes an identification problem which can be resolved by fixing the scale of the unobserved variable. This is the sufficient condition for identification which can be achieved by setting one of the coefficients in the column matrix $\lambda$ to a constant. An alternative is to fix the variance of the unobserved variable $\eta$ to 1 but the former is more convenient for economic interpretation.

\section{A Data Issues}

In this section we discuss the data used for the estimation. The variables used in the estimation are defined in Appendix 1. The data series are quarterly from 1970 to 2004.

The series in levels or differences have been tested for unit roots using the appropriate frequencies. This is shown in Appendix 2. We use the Augmented-Dicky Fuller (ADF) test, Phillips-Perron (PP) test and the Kwiatkowski, Phillips, Schmidt and Shin (KPSS) test. We test 
$\mathrm{I}(2)$ against $\mathrm{I}(1)$ and if we reject $\mathrm{I}(2)$, we test $\mathrm{I}(1)$ against $\mathrm{I}(0)$ as appropriate. All the series have been seasonally adjusted. For particular series that exhibit trends, we include time trend along with a constant in testing for the presence of unit roots using the above tests.

\section{B Estimating the U.S. Shadow Economy using the MIMIC Model}

In this section we describe how the model is estimated using the MIMIC model. We estimate several specifications of the model. We test for identification and then proceed to discuss the sign and significance of the estimated coefficients as well as the Goodness of Fit of our model.

In estimating the size of the $\mathrm{SE}$, the unobserved variable is modelled as a restricted linear function of a set of exogenous factors subject to a random disturbance term $\zeta_{t}$ shown in equation 5:

$$
\eta_{t}=\gamma_{1} x_{1 t}+\gamma_{2} x_{2 t}+\cdots \gamma_{c} x_{c t}+\zeta_{t}
$$

The variables used for estimation are shown in the path diagram in figure 2.

Figure 2: Path diagram of MIMIC Model

All the data have been filtered to make them stationary. Since all of the variables were found to be I(1) stationary, thus the change in the shadow economy is estimated as a restricted linear function of the changes in each of causal variables.

Several model specifications are considered. These are shown in Table 1. In order to check identification we use MIMIC 4-1-2 as an illustration. The model has 2 indicators and 4 causal factors. The coefficient of the index of real $\mathrm{GDP}^{6}$ is normalized to -1 to sufficiently identify the model $\left(\lambda_{2}=-1\right)$. This indicates an inverse relationship between the official and shadow (unofficial) economy.

Table 1: Estimated Coefficients of the MIMIC Models and descriptive statistics

\footnotetext{
${ }^{6}$ The index of real GDP is equal to $($ Real GDP $\mathrm{t}) /\left(\right.$ Real GDP $\left._{1990}\right)$. 
The structural model MIMIC 4-1-2 has 21 structural parameters and the reduced form model has 15 reduced form parameters. Thus, the model is over-identified by the number of additional reduced-form parameters (6). The chi-square statistics tests the null that the covariance matrix is restricted by the number of additional parameters.

In examining Table 1 we observe the sign, and significance of the variables. In terms of the indicators, the $(M 1 / M 2)$ is negatively significant showing that the higher the size of the SE, the lower the demand for broad money relative to narrow money. Table 1 shows an insignificant relationship between the labour force participation rate and the size of the shadow economy. The causal variables, with exclusion of "Ratio of Taxes on production to GDP", have the anticipated sign being positively correlated with the size of the shadow economy.

\section{B.1 Obtaining the size of the Shadow Economy}

In this section, we discuss how we obtain a series for the unobserved variable. According with the reference variable $\left(Y_{2}\right.$, Real $\mathrm{GDP}_{t} /$ Real $\left.\mathrm{GDP}_{1990}\right)$ the unobserved variable is scaled up to a value in 1990, which is our base year. The year selected is 1990 because this is the year in which there are several estimates of the U.S. shadow economy. This assists us to building an average of the estimates. This is shown in table 2.

Table 2: Estimates of the size of U.S. shadow economy (1990)

The index of changes of the SE in the United States as a percentage of GDP in the 1990 is linked to the index of changes of real GDP as follow:

$$
\text { Measurement equation: } \frac{G D P_{t}-G D P_{t-1}}{G D P_{1990}}=-\frac{\tilde{\eta}_{t}-\tilde{\eta}_{t-1}}{G D P_{1990}}
$$

The estimates of the structural model, extracted by MIMIC 5-1-2a, are used to obtain an ordinal time series index for latent variable:

$$
\text { Structural Equation: } \quad \frac{\tilde{\eta}_{t}}{G D P_{1990}}=0.07 X_{2 t}+1.00 X_{6 t}+0.96 X_{7 t}+1.19 X_{8 t}+1.02 X_{9 t}
$$


Finally, the index is scaled to take up to a value of 10.6 percent in 1990 and further transformed from changes respect to the GDP in the 1990 to the shadow economy as ratio of current GDP. These operations are show in the following benchmark equation ${ }^{7}$ :

$$
\frac{\tilde{\eta}_{t}}{G D P_{1990}} \frac{\eta_{1990}^{*}}{\tilde{\eta}_{1990}} \frac{G D P_{1990}}{G D P_{t}}=\frac{\hat{\eta}_{t}}{G D P_{t}}
$$

where:

I. $\quad\left(\tilde{\eta}_{t} / G D P_{1990}\right)$ is the index of SE calculated by eq. 6

II. $\left(\eta_{1990}^{*} / G D P_{1990}=10.6 \%\right)$ is the exogenous estimate of SE;

III. $\quad\left(\tilde{\eta}_{1990} / G D P_{1990}\right)$ is the value of index estimated by eq. 6 in 1990;

IV. $\left(G D P_{1990} / G D P_{t}\right)$ is to convert the index of changes respect to base year in SE respect to current GDP;

V. $\left(\hat{\eta}_{t} / G D P_{t}\right)$ is the estimated SE as a percentage of official GDP.

The ratio between II and III is the coefficient of standardization: it satisfies the condition that estimated SE divided to the GDP in 1990 should be equal to $10.6 \%$. Finally, the third addend of LHS converts the index of changes respect to base year into a ratio between SE and current GDP. In figure 3, the estimated SE as percentage of official GDP calculated by eq. (7) is shown in comparison with other estimates of the SE for U.S. calculated by different methods and extracted by Schneider (2005) and Schneider and Enste (2000).

Figure 3: Shadow Economy as percentage of official GDP

\section{Is there a structural link between the Shadow Economy and Unemployment?}

In this section we adapt a model by Hall (1979) to show that a structural relationship exists between the shadow economy and unemployment rate by examining the dynamics in the flow of workers.

\footnotetext{
${ }^{7}$ As the variables are all differenced to same degree, to calculate the levels of the latent variable multiplying the structural coefficients for raw (unfiltered) data, it is equivalent to compute the changes in the index by multiplying coefficients for the differenced causes and then to integrate them.
} 
Consider a closed economy with a total labour force of $L$ workers. Assume the total labour force is constant. The labour force consists of the stock of workers who are unemployed $(U)$ and the stock of workers who are in employment $(E)$ :

$$
L=U+E
$$

Let $U / L$ be the unemployment rate. To analyse the determinants of the unemployment rate, we consider the flow of workers in and out of unemployment and employment. Let $s$ be the job separation rate and $f$ be the job finding rate. The job separation rate is the rate at which a worker loses a job and becomes unemployed. The job finding rate is the rate at which a worker finds a job and becomes employed. In the steady-state the unemployment rate is constant. This occurs when the rate at which a worker loses a job and becomes unemployed equals the rate at which a worker finds a job and becomes employed. Therefore in the steady-state the job separation rate equals the job finding rate.

$$
f U=s E
$$

The unemployment rate can be solved by substituting $E$ for $(L-U)$ and dividing both sides of equation (9) by the total labour force $(L)$. This is shown in (10):

$$
\frac{f U}{L}=s\left(1-\frac{U}{L}\right)
$$

Solving equation (10) yields the unemployment rate as a function of the job finding rate and the job separation rate.

$$
\frac{U}{L}=\frac{s}{f+s}
$$

From equation (11), it can be seen that an increase in the job separation rate $(s)$ increases the UR and an increase in the job finding rate $(f)$ decreases the unemployment rate. Now from equation (9), we can relate the SE to the UR. Assume in this economy, goods in the official economy are produced using only labour. Labour is the stock of workers who are in employment. Equation (12) shows output in the official economy $\left(Y_{l}\right)$ as a function of technology $(A)$ and the stock of workers who are in employment $(E)$ :

$$
Y=A E .
$$


If technology is assumed to be constant then output in the official economy is produced entirely from the stock of employed workers i.e.

$$
Y=E
$$

Recall equation (10) which states the unemployment rate is the difference between the total labour force and the stock of employed workers. Substituting output in the official economy $\left(Y_{l}\right)$ for $E$ yields the unemployment rate as a negative function of output per worker in the official economy. This is shown in equation (14).

$$
\frac{U}{L}=\frac{L-E}{L}=\frac{\left(1-Y_{1}\right)}{L}
$$

Let total output be the sum of output in the official economy $\left(Y_{1}\right)$ and output in the SE ( $\left.\mathrm{Y}_{2}\right)$. This is represented in equation (15) where $Y_{T}$ is total output, $Y_{l}$ is output produced in the official economy and $Y_{2}$ is output produced in the shadow economy.

$$
Y_{T}=Y_{1}+Y_{2}
$$

Equation (16) shows output in the official economy is the difference between total output and output in the $\mathrm{SE}\left(\mathrm{Y}_{\mathrm{T}}-\mathrm{Y}_{2}\right)$. An increase in output in the SE reduces output in the official economy.

$$
Y_{1}=Y_{T}-Y_{2}
$$

Substituting this difference in to equation (15) yields the UR as a function of the difference between total output per worker and the output in the SE per worker respectively. Output per worker in the shadow economy can also be re-interpreted the share of the SE as proportion of the labour force. Equation (17) shows the UR depends positively on the SE as a proportion of the labour force. It also shows that the larger difference between total output and output in the SE per worker respectively (which is output in the official economy per worker) the lower the UR.

$$
\frac{U}{L}=\frac{1+Y_{2}-Y_{T}}{L}
$$

Rearranging (16) to solve for the SE and substituting for the UR in equation (11) produces the determinants of the SE as a proportion of the labour force as shown in equation (18)

$$
\frac{Y_{2}}{L}=\frac{s}{f+s}+\frac{Y_{T}-1}{L}
$$


Equation (18) produces the key result showing the structural relationship between the relative share of the SE as a proportion of the labour force and the unemployment. An increase in the stock of workers who lose jobs (job separation rate) in the formal sector increases the UR and this causes a rise in the SE as a proportion of the labour force. Workers who lose jobs in the official economy shift their labour services to the SE thus expanding output per worker in the shadow economy. Hence the relative share of the shadow economy with respect to the labour force increases. On the other-hand, an increase in the stock of workers who find jobs (job finding rate) reduces the share of the SE because it reduces the UR. Equation (18) also shows that an increase in total output per worker increases the relative share of the SE to the labour force. Furthermore, an increase in the labour force reduces the share of the SE. A higher stock of workers in the labour force reduces the stock of workers who participate in the SE.

Our theoretical result concurs with Ahn and De La Rica (1997) who explain that the SE is considered to be an alternative source of employment for workers who face "restrictions in the formal sector". Working in the SE denies them access to social security contributions. If workers do not find jobs in the formal sector, they would rather work in the SE than become unemployed. Ahn and De La Rica (1997) also suggest that the working in the SE might be a transitory situation for workers who are waiting to find jobs in the SE. This is because their data set based on living and working conditions in Spain showed that informal sector jobs are inferior to formal sector jobs. Their study showed that there are higher returns to human capital in the formal sector than in the informal sector.

Based on our theoretical argument developed earlier, we examine if a significant positive relationship exists between the shadow economy and the unemployment rate. Early indications of a positive relationships can be observed in Figure 4 which compares the trend of the SE estimated by MIMIC 6-1-2a and the UR for the U.S.

We use MIMIC 6-1-2a instead of MIMIC 5-1-2a because, in the latter specification (see table 1), the unemployment rate figures in the structural equation (eq. 6). In MIMIC 6-1-2a , the UR is not one of regressors used to calculate the SE. Figure 4 shows a direct relationship between the SE as a percentage of GDP and the UR. 
Figure 4: Shadow Economy Vs Unemployment rate

To corroborate the presence of a strong positive relationship between the SE and UR in the U.S., we estimated the correlation between SE and UR. It is found to be 0.63. For our empirical analysis we re-examine the Okun's law which shows an inverse relationship between the growth of the official economy and the unemployment rate. We choose the Okun's law because it is a well established relationship in macroeconomics.

\section{A re-examination of Okun's law - The relationship between unemployment and growth of official economy in presence of Shadow Economy}

In this section, we test the relationship between the unemployment rate, the official economy and the shadow economy by re-examining the Okun's law. As is well known, the Okun's law (developed by Okun, 1962), relates decreases in the UR to increases in output growth. Over time and across countries, the exact quantitative form of this relationship has changed somewhat. However, the negative correlation between changes in the UR and changes in GDP growth is viewed as one of the most consistent empirical relationships in macroeconomics ${ }^{8}$.

In light of the relationship between the SE and the UR developed in section 4, we examine if the SE has a significant effect on the UR. Also of interest is the direction of this relationship. The economic intuition is derived from the hypothesis that a lower growth rate of official GDP from potential output is associated with higher deviations of the unemployment rate from its "natural" level. As previously shown in Section 4, a higher job separation rate increases the UR and this leads to an increase in the number of labourers who work in the unofficial labour market. This causes an increase in the growth of the relative share of the SE. Thus, we argue that an increase in the job separation rate increases the UR and this produces two opposite effects:

- direct effect (observed) - it reduces the growth of official GDP;

\footnotetext{
${ }^{8}$ In literature the association between changes in the unemployment rate and output growth can become less reliable for a variety of reasons, however the predominant factor that has tended to undermine specific representations of Okun's law has been changes in productivity. See among others: Dixon and Thomson (2000), Kaufman (1988), Sögner and Stiassny (2002).
} 
- indirect effect (partially unobserved) ${ }^{9}$ - it increases the growth of the SE via the increase in the relative share of SE to the labour force.

The increase in the relative share of the SE causes a decrease in growth official GDP but by less than the direct impact of unemployment rate.

Consequently, our empirical results suggest that the presence of the SE stabilizes the effect of higher unemployment on the growth rate of official output through its ability to absorb the unemployed into the unofficial labour force as workers in the SE. This is confirmed by the significant statistical relationships among the growth rate of official GDP, changes in UR and the growth of the SE in the U.S. economy. The statistical correlations between 1970 to 2004 are shown in figure 5.

Figure 5: Growth of Official GDP, Changes of Unemployment and Growth of Shadow Economy

Table 3 shows the estimates obtained based on the standard relation given by Okun's law:

$$
g_{t}^{Y}=\alpha_{0} \Delta u_{t}+\varepsilon_{t}
$$

Where: $g_{t}^{Y}=\left(g_{t}^{\text {off }}-\bar{g}_{(70-04)}^{Y}\right)$ and $g_{t}^{\eta}=\left(g_{t}^{\text {shad }}-\bar{g}_{(70-04)}^{\eta}\right)$ indicating respectively, the difference of (quarterly) growth rate of the official gross domestic product $\left(g_{t}^{\text {off }}\right)$ and the shadow economy $\left(g_{t}^{\text {shad }}\right)$ from their averages calculated over the period 1970 to $2004 ; \Delta u_{t}$ is the first difference of unemployment rate; $\varepsilon_{t}$ are the i.i.d residuals.

Table 3: Estimation output of regression: $g_{t}^{Y}=\alpha_{0} \Delta u_{t}+\varepsilon_{t}$

The estimates show an inverse relationship between changes in unemployment and the growth rate of official output. Next we use a modified version of Okun's law by including the shadow

\footnotetext{
${ }^{9}$ It is only "partially unobserved" because shadow activities create an extra value added that can be spent in the official economy.
} 
economy estimated by MIMIC 6-1-2a. We utilize this alternative model specification to estimate the size SE instead of MIMIC 5-1-2a. In this sense, we attempt to control for collinearity between regressors of eq. (20):

$$
g_{t}^{Y}=\alpha_{1} \Delta u_{t}+\beta g_{t}^{\eta}+\varepsilon_{t}
$$

Table 4 shows the output of modified Okun's equation.

Table 4: Estimation output of regression: $g_{t}^{Y}=\alpha_{1} \Delta u_{t}+\beta g_{t}^{\eta}+\varepsilon_{t}$

The estimated output shows a lower effect of differences in UR on the growth of official GDP $\left(\alpha_{1}<\alpha_{0}\right)$. In authors' view estimated coefficients should be considered cautiously. The OLS regression coefficients are biased when one omits a relevant variable, and the direction and size of the bias depends on the correlation between the omitted and included RHS variables. In this case, the correlation between changes in UR and the structural growth of SE affects the estimate of statistical relationship between $\Delta u_{t}$ and $g_{t}^{Y}$. In this sense, the difference between $\alpha$-coefficients can be biased for omitted variables. In this case, the correlation between changes in UR and the structural growth of SE could cause an overestimation of the compensatory effect that SE has on GDP as a consequence of the changes in UR.

The econometric results confirm an over-evaluation in Okun's law of the effects that changes in unemployment have on the growth rate of official GDP. According with the conclusions of the theoretical model presented in paragraph 4, we deduce therefore that SE tends to cushion the effects of changes in unemployment on the official GDP.

The significant difference in $\alpha$-coefficients $\left(\alpha_{1}\right.$ is about one-fourth of $\left.\alpha_{0}\right)$ is evidence for a direct relationship between changes in UR and the growth of the SE.

Our estimations show that the presence of the SE acts as a buffer as it absorbs some of the unemployed workers from the official economy into the SE. It reduces the impact of higher unemployment on official output. Therefore the SE is an asset rather than a liability to the official 
economy. Since the SE is able to aid in cushioning the adverse effects of government policy, ways of incorporating the SE into the wider economic network should be explored.

Bajada (2005) shows a positive relationship between the rate of unemployment and the shadow economy in Australia. He introduces the concept of an "income effect" and "substitution effect" in explaining the effect of UR and the SE. A decrease in consumption leads to a decrease in output in the official and SE respectively. This is the "income effect". The decrease in economic activity in the official economy increases the UR. As a result, workers who cannot find a job in the official economy switch the supply of labour to the SE. This is the "substitution effect". He argues that the advantage of the substitution effect is that it acts as an automatic stabilizer in decreasing the volatility of the business cycle of the SE. Consequently, a higher UR reduces the volatility of the aggregate business cycle. However, his results showed that the effect of the automatic stabilizer is limited because the income effect dominates the substitution effect.

In. U.S. economy we don't find evidence for the "income effect". It is because official and unofficial economies are inversely correlated. That being stated, SE is able to reduce the volatility of the aggregate business cycle.

According with Bajada (2005) the issue of how changes in the UR affect the SE is crucial not only from a business cycle perspective but also from the perspective of public funding of welfare assistance programmes.

In U.S. economy, the positive relationship between UR and SE implies the following policy propositions: (a) changes in the UR can potentially act as an automatic stabilizer dampening the volatility of the business cycle, and (b) government requires more stringent monitoring of those receiving welfare assistance to avoid that unemployment benefit became incentive to participate in the shadow labour force.

\section{Conclusion}

In this paper, we estimate the size of the shadow economy in the United States as well as examine if a structural relationship exists between the UR and the SE. The SE was estimated using the MIMIC model. Our results show that the size of the SE varies from fourteen to nineteen 
percent between 1970 and 1983 and then decreases steadily up to 7 percent of official GDP in 2004.

The MIMIC analysis points out the major factors that determine the size and development of SE. The social security contributions as ratio of official GDP, the unemployment rate and the rate of self-employment as a percentage of the labour force are the main determinants of SE in USA. They have the expected positive sign and are statistically significant.

We find also some "unusual" results. In particular, the tax burden has either an insignificant influence or in the case of corporate taxation a statistically significant negative influence.

Authors' explanation for this puzzling result is twofold. From a theoretical viewpoint, the difference between US outcome and other developed countries can be linked to the evidence that there are only a few OECD member countries with a lower tax burden than the United States (Herd and Bronchi, 2001). The total amount of tax revenue raised in the United States has increased only modestly over the past 35 years relative to GDP. In this sense, we conclude that a fair level of taxation and moderately increasing trend could motivate the exclusion of tax burden among the causes of the development of the U.S. Shadow Economy.

From a methodological perspective, the reappraisal of the tax burden as causes of SE respect to alternative estimate provided by similar studies (i.e. Schneider, 2005) can be motivated also by the different approaches followed in these researches. While we develop a single country analysis, the above mentioned paper is based on panel data. It means to give different interest on the crosscountry dimension or the cluster composition (OECD countries, Developing countries, etc.) instead of the time dimension. In this sense, we believe that a single country analysis is able to take better into account the long-run relationship among causes and SE.

Several specifications of the MIMIC model were used and a significant positive relationship was found between UR and the SE. This result was an early indicator of beneficial role the SE plays in reducing the impact of unemployment on the official economy. A downturn in the economic official activities leads to a loss of jobs and thus drives part of unemployed into the shadow activities. 
We adapt a model by Hall (1979) to examine the relationship between the SE and the UR. The economic intuition is that the higher the rate at which people lose job in the formal sector, the higher the unemployment rate. Consequently, the relative share of the SE to the labour force increases. Bajada (2005) in his study shows a positive relationship between the UR and the SE in Australia. His results showed that the effect of the automatic stabilizer is limited because the income effect dominates the substitution effect. In. U.S. economy we don't find evidence for the "income effect" then SE reduces the volatility of the aggregate business cycle. According to Bajada (2005) policymakers who make use of official statistics to gauge their policies may be unconscious of the true volatility in the business cycle generated by the SE.

We suppose that the relationship between the SE and UR reduces the magnitude of the effect of changes in the unemployment rate on output growth (known as Okun's law). Okun's rule of thumb tells us that GDP rises when the unemployment rate decrease (eq. 19). We suggest that the Okun's coefficient is biased (overstated) as a consequence of the omission of the shadow economy (eq. 20).

This becomes the motivation to modify the Okun's law to include the SE. Our results show a direct relationship between the unemployment rate and the growth of the shadow economy while maintaining the a-priori relationship between the official growth rate and the rate of unemployment rate. An increase in unemployment reduces official growth rate by $1.54 \%$. However, including the SE shows that an increase in unemployment leads to a smaller reduction in the official growth rate of $0.04 \%$.

Our findings is that the SE plays a beneficial role in cushioning the effect of unemployment on the official economy because it absorbs the "excess labour force" following demand restrictions in the official economy into the SE. Therefore the presence of the SE is an asset rather than a liability to the growth of the official economy. The SE creates an extra added value that can be spent in the official economy ${ }^{10}$ thus having a positive effect on the latter. Furthermore, people involved in informal production activities are usually characterized by lower level of personal income, therefore, underground production modifies (improves) the distribution of income in society. The

\footnotetext{
${ }^{10}$ Schneider and Enste (2000) for instance state that at least two-thirds of the income earned in SE is immediately spent in the official economy.
} 
SE is characterized by very low costs of labour. In addition, there is higher freedom of entry and exit in the shadow economy. This contributes to improving competitiveness in the labour market by making the labour market more flexible to changes in the demand and supply of labour.

Therefore, in contrast to the view that the SE is a main concern for policymakers, according to our findings, government should be addressing their policies to move economic activities in the SE towards official economy rather than eliminate them. Incorporating the SE would decrease significantly the distortions in economic indicators such as the UR and growth rate which the government rely on to formulate policy.

Given that the estimation of the SE, whose nature is unobservable, is very complicated, any theoretical and empirical inference derived by these figures should be considered always as an approximation. In light of these difficulties, we believe that the results drawn from these estimations should be interpreted cautiously with a full understanding of their limitations.

However, the results provide an interesting analysis as to the short-run and long-run implication of the shadow economy on the rate of unemployment and vice versa ${ }^{11}$.

\section{Acknowledgements}

We thank an anonymous referee for very valuable comments.

\footnotetext{
${ }^{11}$ The authors use a Structural VAR model to show a structural relationship between the unemployment rate and the shadow economy in the long-run.
} 


\section{APPENDIX 1: SOURCES OF DATABASE}

The data are quarterly and seasonally adjusted. The sources are: Bureau of Economic Analysis (BEA) and Bureau of Labor Statistics Data (BLS).

Table 5: Dataset

\section{APPEndiX 2: ANALYSis OF NON-Stationarity}

In this appendix we display the tests employed to detect the order of integration in the time series. The pioneer in tackling the problem of non-stationarity in the MIMIC models has been Giles (1995). As Giles and Tedds (2002) point out, the most appropriate way “...to consider the non-stationary element is to consider the possibility of cointegration. Unfortunately, there is no established literature which may serve as a guide to this procedure in the context of the MIMIC model". To discover the unit roots, the Augmented Dickey-Fuller (ADF) Test and the PhilliphsPerron (PP) Test are used; to choose a number of lags sufficient to remove serial correlation in the residuals and the automatic selection of bandwidth we have employed the Schwarz information criterion (ADF) and the Newey-West test using Bartlett Kernel (PP). In the following tables the pvalue of the abovementioned tests is reported, while the null hypothesis is the presence of the unit root, and therefore a value greater than 0.05 indicates non-stationary time series. A third unit root test is applied, namely the Kwiatkowski, Phillips, Schmidt and Shin Test (KPSS, 1992) ${ }^{12}$. This test differs from the others in that the series is assumed to be (trend-) stationary, according to the null hypothesis. The table 7 shows the statistical test: we test $\mathrm{I}(2)$ against $\mathrm{I}(1)$ and if we reject $\mathrm{I}(2)$, we test $\mathrm{I}(1)$ against $\mathrm{I}(0)$ as appropriate, if the estimated values exceed the respective critical values ${ }^{13}$, stationarity must be rejected. The critical values for the LM test statistics are based upon the asymptotic results presented in KPSS (table 1, p. 166).

- $\quad$ KPSS test equation with constant critical values are: $0.347(10 \%), 0.463(5 \%), 0.739(1 \%)$;

\footnotetext{
${ }^{12}$ The Kernel function was chosen according to Bartlett's criteria and the Newey-West method is used for bandwidths.

${ }^{13}$ As the ADF and KPSS tests are adversely sensitive to the presence of breaks in the data, by showing critical values it is possible to check these values with Kurozumi's (2002, table 3, p. 86) critical values. Kurozumi's (2002) modified KPSS test allows to use consider the distortion in the statistical test distribution caused by a structural break.
} 
- $\quad$ KPSS test equation with constant and trend: $0.119(10 \%), 0.146(5 \%), 0.216(1 \%)$.

The econometric software Eviews 4.1 was used in to perform this analysis.

Table 6: Unit root analysis

Figure 6: Plots of Variables 


\section{References}

Ahn, N. and De La Rica, S. (1997) The underground economy in Spain: an alternative to unemployment? Applied Economics, 29 (6), 733 - 743.

Alañón, A. and Gómez-Antonio, M. (2005) Estimating the size of the shadow economy in Spain: a structural model with latent variables, Applied Economics, 37(9), 1011- 1025.

Arimah, B.C. (2001) Nature and Determinants of thr Linkages between Informal and Formal Sector Enterprises in Nigeria, African Development Review, 13(1), 114-131.

Bajada, C. (2005) Unemployment and the Underground Economy in Australia, Applied Economics, 37(2), 177-189.

Bertola, G. and Garibaldi, P. (2003) The Structure and History of Italian Unemployment, CESifo Working Papers, n.907.

Boeri, T. and Garibaldi, P. (2002) Shadow Activity and Unemployment in a Depressed Labor Market, CEPR Discussion papers, n.3433.

Bordignon, M. and Zanardi, A. (1997) Tax Evasion in Italy, Giornale degli Economisti e Annali di Economia, 56, 169-210.

Cebula, R.J. (1997) An Empirical Analysis of the Impact of Government Tax and Auditing Policies on the Size of the Underground Economy: The Case of the United States, 19931994, American Journal of Economics and Sociology, 56(2), 173-185.

De Gijsel, P. (1984) Ökonomische Theorie des Schwarzarbeitsangebots und der Mehrfachbeschäftigung, in Bernd (Eds.), Gretschmann, K.H., Rolf, G., Mettelsiefen Schattenwirtschaft. Wirtschafts- und Sozialwissenschaftliche Aspekte, Internationale Erfahrungen. Göttingen: Vandenhoeck und Rubrecht, 76-96.

Dell'Anno, R. (2007) The Shadow Economy in Portugal: an analysis with the MIMIC approach, Forthcoming on Journal of Applied Economics.

Dell'Anno, R. (2003) Estimating the Shadow Economy in Italy: a Structural Equation Approach, Working paper, n.03-7, University of Aarhus, Department of Economics, Denmark.

Dell'Anno, R. and Schneider, F. (2003) The Shadow Economy of Italy and other OECD Countries: What do we know? Journal of Public Finance and Public Choice / Economia delle scelte pubbliche, 21(2/3), 97-120. 
Dixon, R. and Thomson, J. (2000) Okun's Law And Movements Over Time In The Unemployment Rate In Australia”, Research Paper, n. 741, University of Melbourne, Australia.

Enste, D.H. (2003) Shadow Economy and Institutional Change in Transition Countries in Boyan Belev (eds.), The Informal Economy in the EU Assessment Countries: Size, Scope, Trends and Challenges of the Process of EU-enlargement, Center for Study of Democracy, Sofia, 81-114.

Feige, E.L. (1981) The UK's Unobserved Economy: A Preliminary Assessment, Journal of Economic Affairs, 1, 205-212.

Friedman, E.; Johnson, S., Kaufmann, D. and Zoido-Labton, P. (2000) Dodging the grabbing hand: The determinants of unofficial activity in 69 countries, Journal of Public Economics, 76(4), 459-493.

Garibaldi, P. and Wasmer, E. (2001) Labor Market Flows and Equilibrium Search Unemployment, IZA Discussion Paper Series, n. 406.

Gërxhani, K. (1999) The informal sector in developed and less developed countries, Discussion Papers, n. 083/2, Tinbergen Institute, The Netherlands.

Giles, D.E.A. (1995) Measuring the size of the hidden economy and the tax gap in New Zealand: an econometric analysis, Working Paper, N. 5a, on Monitoring the Health of the Tax System, Inland Revenue Department, Wellington, New Zealand.

Giles, D.E.A., Tedds, L.M. and G.T. Werkneh. (2002) The Canadian Underground and Measured Economies: Granger Causality Results, Applied Economics, 34, 2347-2352.

Giles, D.E.A. and Tedds, L.M. (2002) Taxes and the Canadian Underground Economy. Canadian Tax paper, n.106, Canadian Tax Foundation, Toronto, Canada.

Hall, R.E. (1979) A Theory of the Natural Rate of Unemployment and the Duration of Unemployment, Journal of Monetary Economics 5, 153-169.

Herd, R. and Bronchi, C. (2001) Increasing efficiency and reducing complexity in the tax system in the United States, OECD Economics Department Working Papers no. 313. Paris.

Johnson, S., Kaufmann, D. and Shleifer, A. (1997) The Unofficial Economy in Transition, Brooking Papers of Economic Activity, 2, 159-221. 
Johnson, S., Kaufmann, D. and Zoido-Lobaton, P. (1998a) Regulatory Discretion and the Unofficial Economy, American Economic Review, 88(2), 387-92.

Johnson, S., Kaufmann, D. and Zoido-Lobaton, P. (1998b) Corruption, Public Finances and the Unofficial Economy, Policy Research Working Paper Series, n.2169, The World Bank Washington, D.C., USA.

Jöreskog, K. and Goldberger, A.S. (1975) Estimation of a model with multiple indicators and multiple causes of a single latent variable, Journal of the American Statistical Association, 70, 631-639.

Jöreskog, K. and Sörbom, D. (1993) LISREL 8, User's Reference Guide. Chicago: Scientific Software International.

Kaufman, R.T. (1988) An International Comparison of Okun's Laws, Journal of Comparative Economics, 12, 182-203.

Kurozumi, E. (2002) Testing for stationarity with a break, Journal of Econometrics, 108(2), 63-99.

Kwiatkowski, D., Phillips, P.C.B., Schmidt, P. and Shin, Y. (1992) Testing the null hypothesis of stationarity against the alternative of a unit root, Journal of Econometrics, 54, 159-178.

Lackó, M. (1999) Hidden Economy an Unknown Quantity? Comparative Analyses of Hidden Economies in Transition Countries in 1989-95, Working Paper, n. 9905, Department of Economics, University of Linz, Austria.

Lemieux, T., Fortin, B. and Fréchette, P. (1994) The Effect of Taxes on Labor Supply in the Underground Economy, The American Economic Review, 84, 231-254.

MacKinnon, J.G. (1996) Numerical distribution functions for unit root and co-integration tests, Journal of Applied Econometrics, 11, 601-618

OECD (2002) Handbook for measurement of the non observed economy, Paris.

Riebel, V. (1983) Die Schwarzarbeit als Problem der Zeitallokation. Frankfurt am Main, Bern, New York: Peter Lang.

Riebel, V. (1984) Arbeitszeitverkurzung und Schwarzarbeit Auswirkungen einer Verkurzung der Wochenarbeitzeit auf das Individuelle Arbeitsangebot", Zeitschrift fur Wirtschafts-und Sozialwissenschaften, 104(5), 515-538. 
Okun, A.M. (1962) Potential GNP: Its Measurement and Significance, Proceedings of the Business and Economics Section, American Statistical Association, Washington D.C., USA, 98-103.

Schneider, F. and Klingmair, R. (2004) Shadow economies around the world: what do we know? Working Paper, 0403, (April), Department of Economics, Johannes Kepler University of Linz, Austria.

Schneider, F. (2005) Shadow economies around the world: what do we really know? European Journal of Political Economy, 21(3), 598-642.

Schneider, F. and Enste, D.H. (2002) The Shadow Economy: Theoretical Approaches, Empirical Studies, and Political Implications, Cambridge, Cambridge University Press.

Schneider, F. and Enste, D.H. (2002) Hiding in the Shadows, the Growth of the Underground Economy, International Monetary Fund, Economic Issues No. 30.

Schneider, F. and Enste, D.H. (2000) Shadow economies: size, causes and consequences, Journal of Economic Literature, 38, 77-114.

Sögner, L. and Stiassny, A. (2002) An Analysis on the Structural Stability of Okun's Law: A Cross-Country Study, Applied Economics, 34, 1775-87.

Swaminathan, M. (1991) Understanding the informal sector: A survey. WIDER Working Paper, $\mathrm{n}$. 95. Finland.

Tanzi, V. (1999) Uses and Abuses of Estimates of the Underground Economy, The Economic Journal, 109, 338-347. 


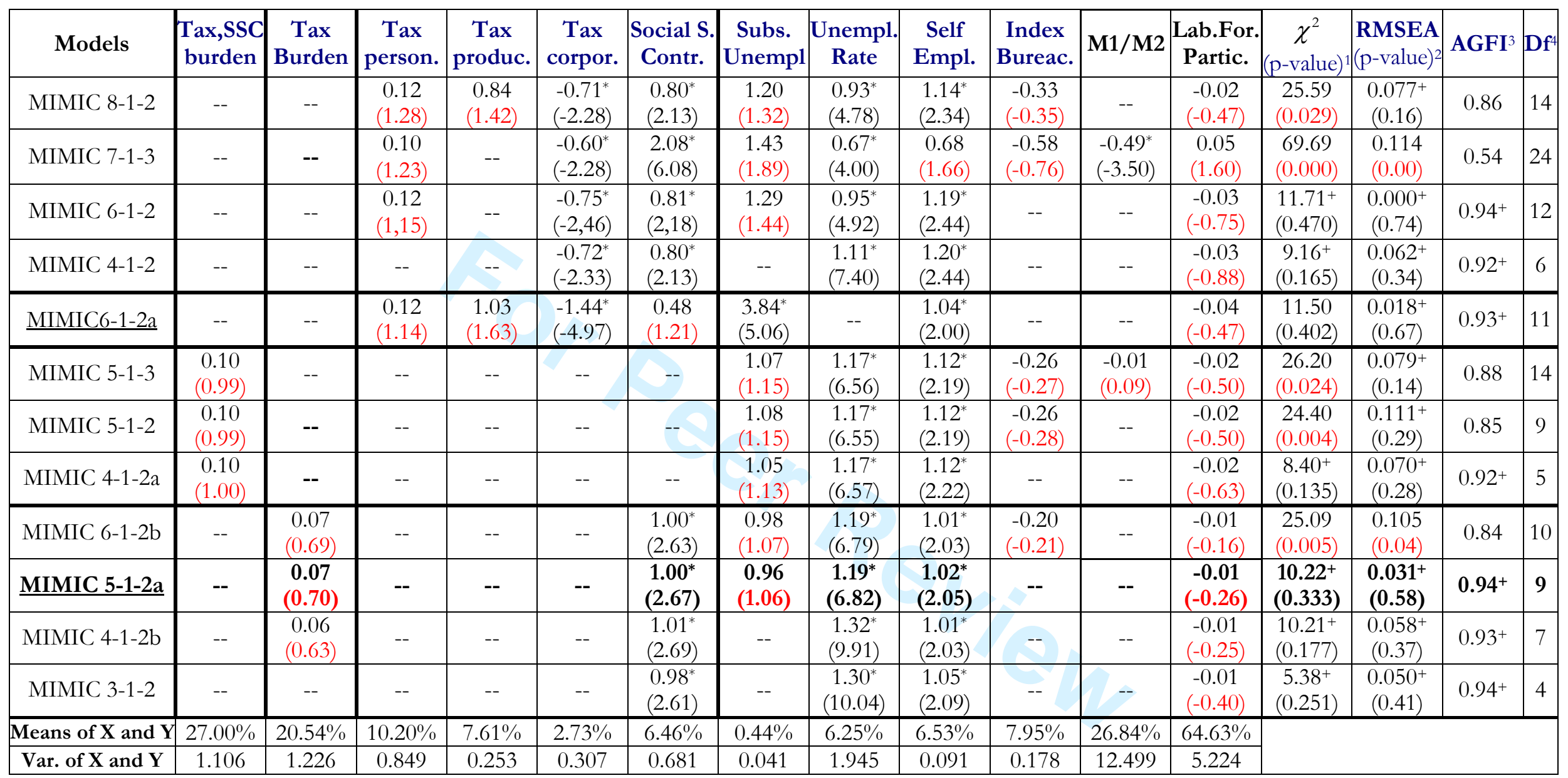

\section{Notes:}

t-statistic are given in parentheses. ${ }^{*}$ Means It-statisticl $>1.96$.

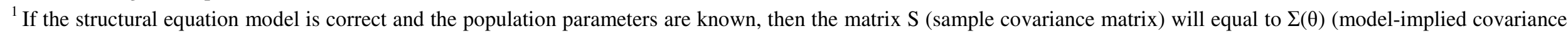
matrix) therefore the perfect fitting correspond to $\mathrm{p}$-value $=1.0$; This test has a statistical validity if there are large sample and multinormal distributions

${ }^{2}$ p-value for Test of Close Fit $\left(\right.$ RMSEA < 0.05). ${ }^{+}$Means good fitting ( $\mathrm{p}$-value $\left.>0.05\right)$.

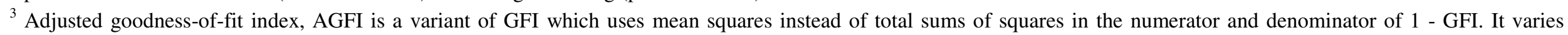
approximately from 0 to 1 . AGFI should also be at least 0.90 .

${ }^{4}$ The degrees of freedom are determined by $0.5(d+c)(d+c+1)-t$, where "d" is the number of indicators, "c" the number of causes and " $t$ " is the number of free parameters. 
Table 2: Estimates of the size of U.S. shadow economy (1990)

\begin{tabular}{lcc}
\hline \multicolumn{1}{c}{ Author } & Method & Size of Shadow Economy \\
\hline Johnson et al. (1998b) & Currency Demand Approach & $13.9 \%$ \\
\hline Làcko (1999) & Physical Input (Electricity) & $10.5 \%$ \\
\hline Schneider and Enste (2000) & Currency Demand Approach & $7.5 \% *$ \\
\hline
\end{tabular}

Note: *(mean over 1989-93) 
Table 3: Estimation output of regression: $g_{t}^{Y}=\alpha_{0} \Delta u_{t}+\varepsilon_{t}$

Dependent Variable: $\mathbf{g}^{\mathbf{Y}}$

Method: Least Squares

Sample: 1970:2 2004:4

Included observations: 139

\begin{tabular}{lrlrr}
\hline \multicolumn{1}{c}{ Variable } & Coefficient & Std. Error & t-Statistic & Prob. \\
\hline \hline \multicolumn{1}{c}{$\Delta \mathbf{u}$} & -0.015440 & 0.001494 & -10.33588 & 0.0000 \\
\hline \hline R-squared & 0.436344 & Mean dependent var & $-1.00 \mathrm{E}-18$ \\
Adjusted R-squared & 0.436344 & S.D. dependent var & 0.008549 \\
S.E. of regression & 0.006418 & Akaike info criterion & -7.252171 \\
Sum squared resid & 0.005685 & Schwarz criterion & -7.231060 \\
Log likelihood & 505.0259 & Durbin-Watson stat & 2.293277 \\
\hline \hline
\end{tabular}


Table 4: Estimation output of regression: $g_{t}^{Y}=\alpha_{1} \Delta u_{t}+\beta g_{t}^{\eta}+\varepsilon_{t}$

Dependent Variable: $\mathbf{g}^{\mathbf{Y}}$

Method: Least Squares

Sample: 1970:2 2004:4

Included observations: 139

\begin{tabular}{lllll}
\hline \hline \multicolumn{1}{c}{ Variable } & Coefficient & Std. Error & t-Statistic & Prob. \\
\hline \hline \multicolumn{1}{c}{$\mathbf{\Delta} \mathbf{u}$} & -0.003648 & 0.001617 & -2.256117 & 0.0256 \\
$\mathbf{g}^{\mathbf{n}}$ & -0.182131 & 0.017856 & -10.19982 & 0.0000 \\
\hline \hline R-squared & 0.679630 & Mean dependent var & $-1.00 \mathrm{E}-18$ \\
Adjusted R-squared & 0.677292 & S.D. dependent var & 0.008549 \\
S.E. of regression & 0.004856 & Akaike info criterion & -7.802750 \\
Sum squared resid & 0.003231 & Schwarz criterion & -7.760527 \\
Log likelihood & 544.2911 & Durbin-Watson stat & 2.227917 \\
\hline \hline
\end{tabular}


Table 5: Dataset

\begin{tabular}{|c|c|c|c|}
\hline & CAUSES & Sources & Annotations \\
\hline $\mathrm{X}_{1}$ & $\begin{array}{l}\text { Overall tax and social } \\
\text { security burden }\end{array}$ & BEA & $\left(X_{3}+X_{4}+X_{5+} X_{6}\right)$ \\
\hline $\mathrm{X}_{2}$ & Tax burden & BEA & $\left(X_{3}+X_{4}+X_{5}\right)$ \\
\hline$X_{3}$ & $\begin{array}{l}\text { Personal Current } \\
\text { Taxes/GDP }\end{array}$ & BEA & $\begin{array}{l}\text { Table 3.1. Government Current Receipts and Expenditures/ Table } \\
\text { 1.1.5. Gross Domestic Product. Series Id: (W055RC1/A191RC1) }\end{array}$ \\
\hline $\mathrm{X}_{4}$ & $\begin{array}{l}\text { Taxes on production } \\
\text { and imports/GDP }\end{array}$ & BEA & $\begin{array}{l}\text { Table 3.1. Government Current Receipts and Expenditures/ Table } \\
\text { 1.1.5. Gross Domestic Product. Series Id: (W056RC1/A191RC1) }\end{array}$ \\
\hline $\mathrm{X}_{5}$ & $\begin{array}{l}\text { Taxes on corporate } \\
\text { income/GDP }\end{array}$ & BEA & $\begin{array}{l}\text { Table 3.1. Government Current Receipts and Expenditures/ Table } \\
\text { 1.1.5. Gross Domestic Product. Series Id: (W025RC1/A191RC1) }\end{array}$ \\
\hline$X_{6}$ & $\begin{array}{l}\text { Contributions for } \\
\text { government social } \\
\text { insurance/GDP }\end{array}$ & BEA & $\begin{array}{l}\text { Table 3.1. Government Current Receipts and Expenditures/ Table } \\
\text { 1.1.5. Gross Domestic Product. Series Id: (A061RC1/A191RC1) }\end{array}$ \\
\hline $\mathrm{X}_{7}$ & $\begin{array}{c}\text { Government } \\
\text { Unemploym. insurance }\end{array}$ & BEA & $\begin{array}{l}\text { Table 2.1. Personal Income and Its Disposition/ Table 1.1.5. } \\
\text { Gross Domestic Product. Series Id: (W025RC1/A191RC1) }\end{array}$ \\
\hline $\mathrm{X}_{8}$ & $\begin{array}{c}\text { Unemployment/ } \\
\text { Civilian Labor Force }\end{array}$ & BLS & Series Id: LNS14000000 \\
\hline $\mathrm{X}_{9}$ & $\begin{array}{c}\text { Self-Employment } \\
\text { /Civilian Labor Force }\end{array}$ & BLS & $\begin{array}{l}\text { Employment Level - Non-agricultural, Self-employed Workers } \\
\text { /Civilian L.F. (LNS12032192/ LNS11000000) }\end{array}$ \\
\hline $\mathrm{X}_{10}$ & Index of bureaucracy & BLS & $\begin{array}{l}\text { Government employment excludes postal (Federal) and } \\
\text { education (State and local)/ Civilian Labor Force } \\
\text { (CES9091100001/LNS11000000) }\end{array}$ \\
\hline \multicolumn{4}{|c|}{ INDICATORS } \\
\hline $\mathrm{X}_{4}$ & M1/M2 & BEA & $\begin{array}{c}\text { International Monetary Fund } \\
\text { Series Id: (11159MA.ZF/11159MB.ZF) } \\
\end{array}$ \\
\hline $\mathrm{X}_{5}$ & Index of real GDP & BEA & $\begin{array}{l}\text { Table 1.1.6. Real Gross Domestic Product, Chained Dollars. } \\
\text { Billions of chained (2000) dollars. } \\
\text { Seasonally adjusted at annual rates; } \\
\text { Series Id: A191RX1/(Real GDP Q1:1990) } \\
\end{array}$ \\
\hline $\mathrm{X}_{6}$ & $\begin{array}{l}\text { Civilian labor force } \\
\text { participation rate }\end{array}$ & BLS & $\begin{array}{c}\text { Labor Force Statistics from the Current Population Survey } \\
\text { Series Id: LNS11300000 }\end{array}$ \\
\hline
\end{tabular}


Table 6: Unit root analysis

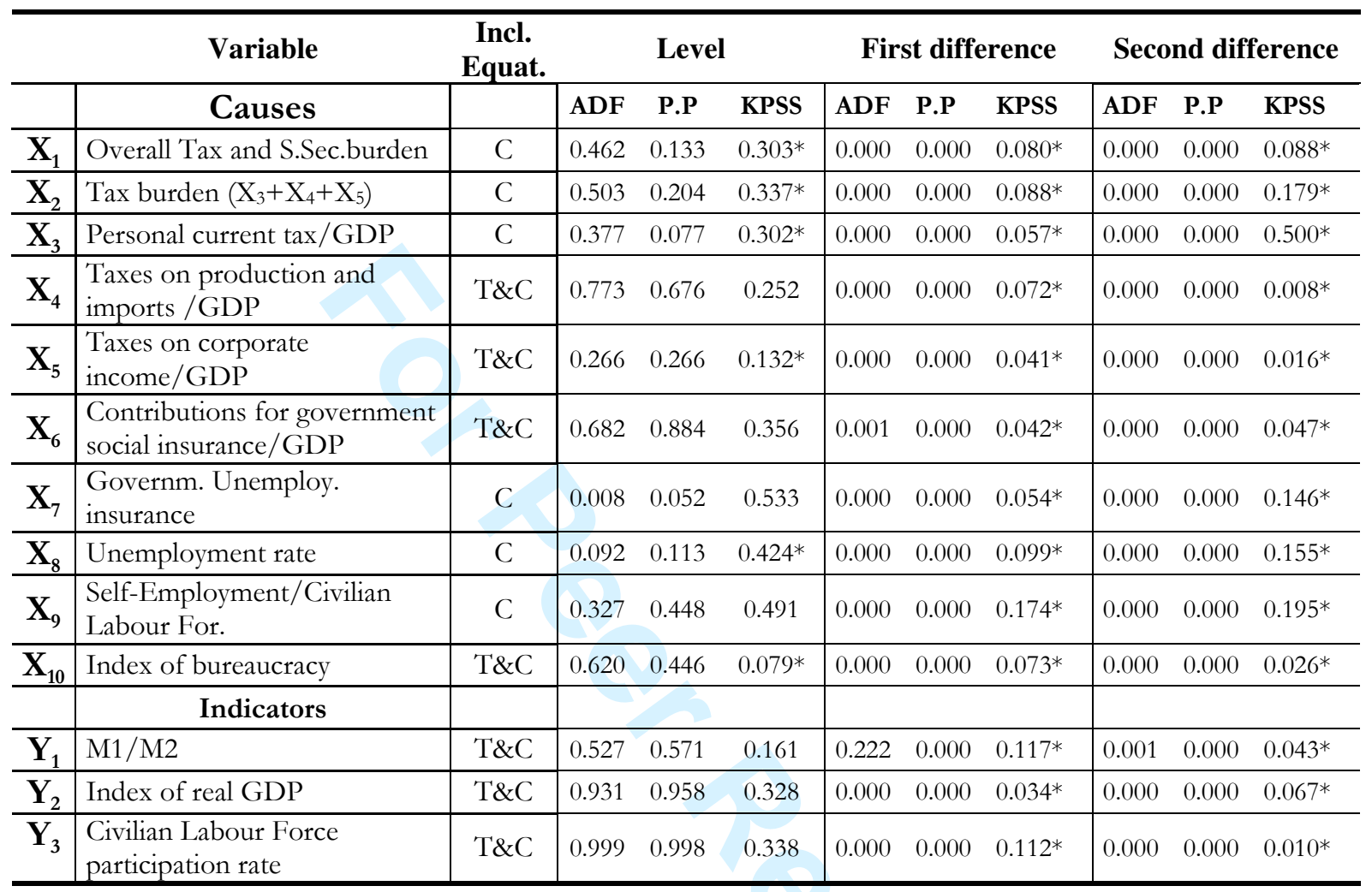

Notes: For ADF and PP show the MacKinnon (1996) one-sided p-values; the statistical tests are shown for KPSS; * means stationary at 0.05 level. 
Figure 1: ISTAT Framework of Non-Observed Economy

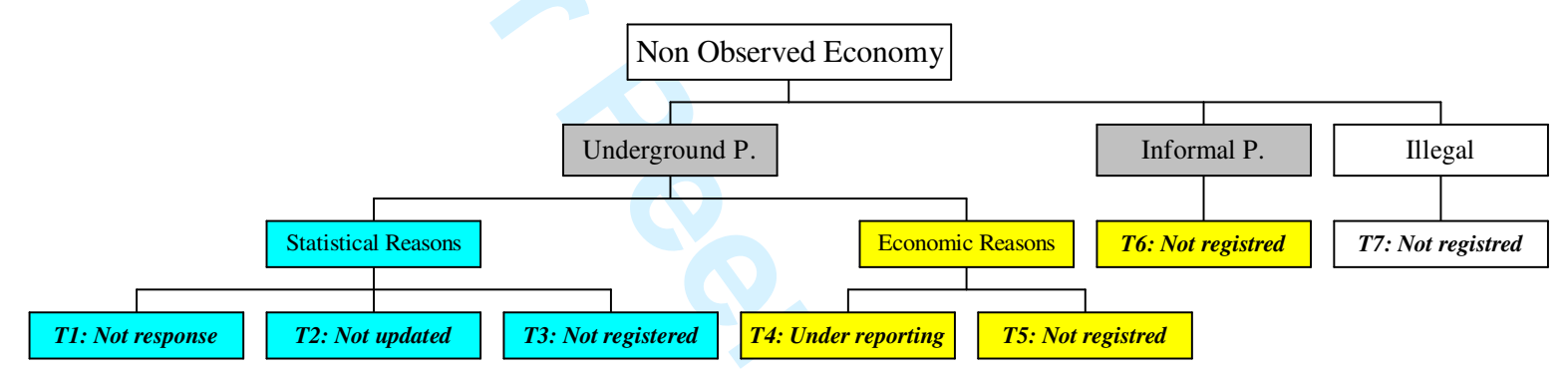


Figure 2: Path diagram of MIMIC Model

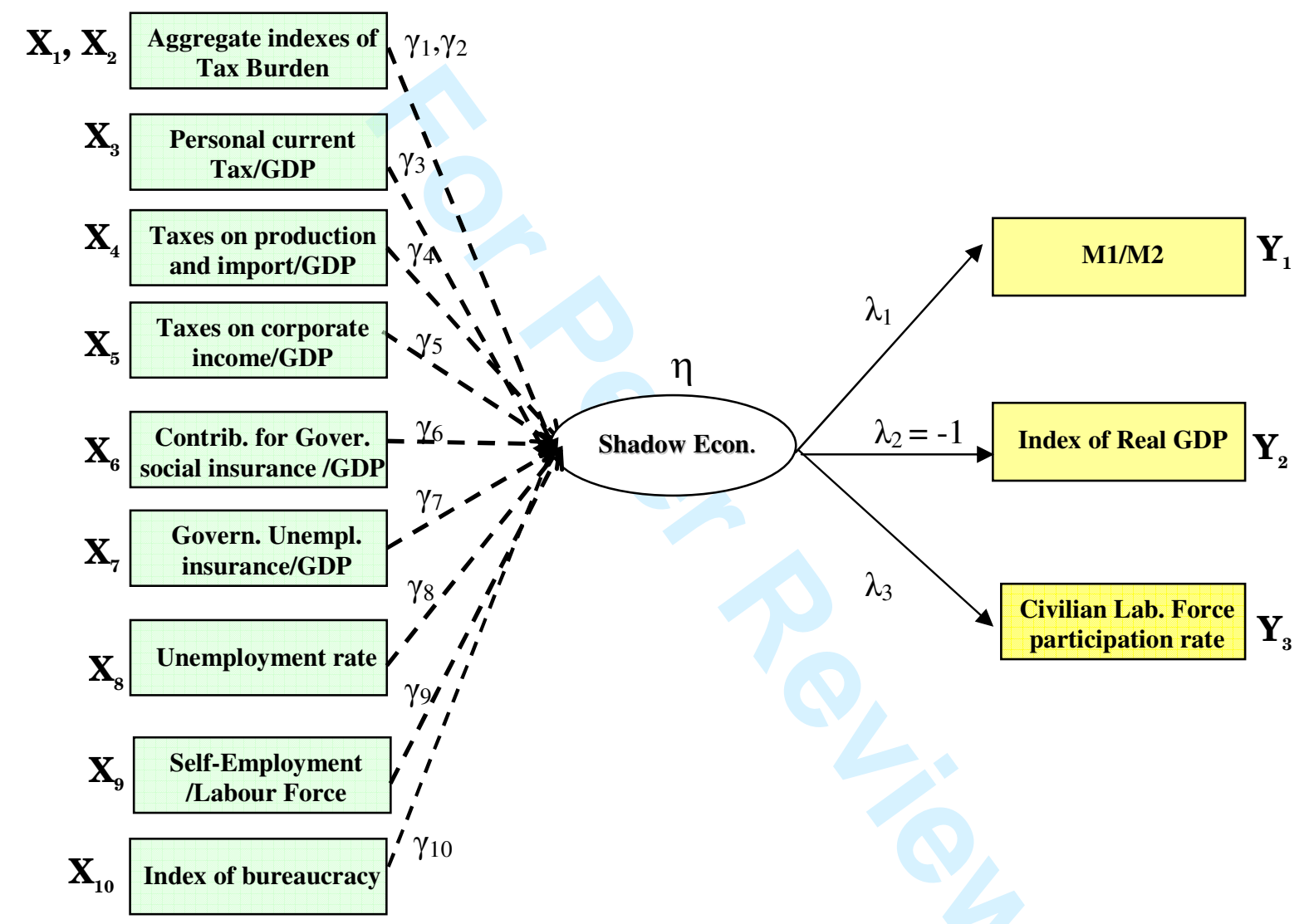


Figure 3: U.S. Shadow Economy as percentage of official GDP
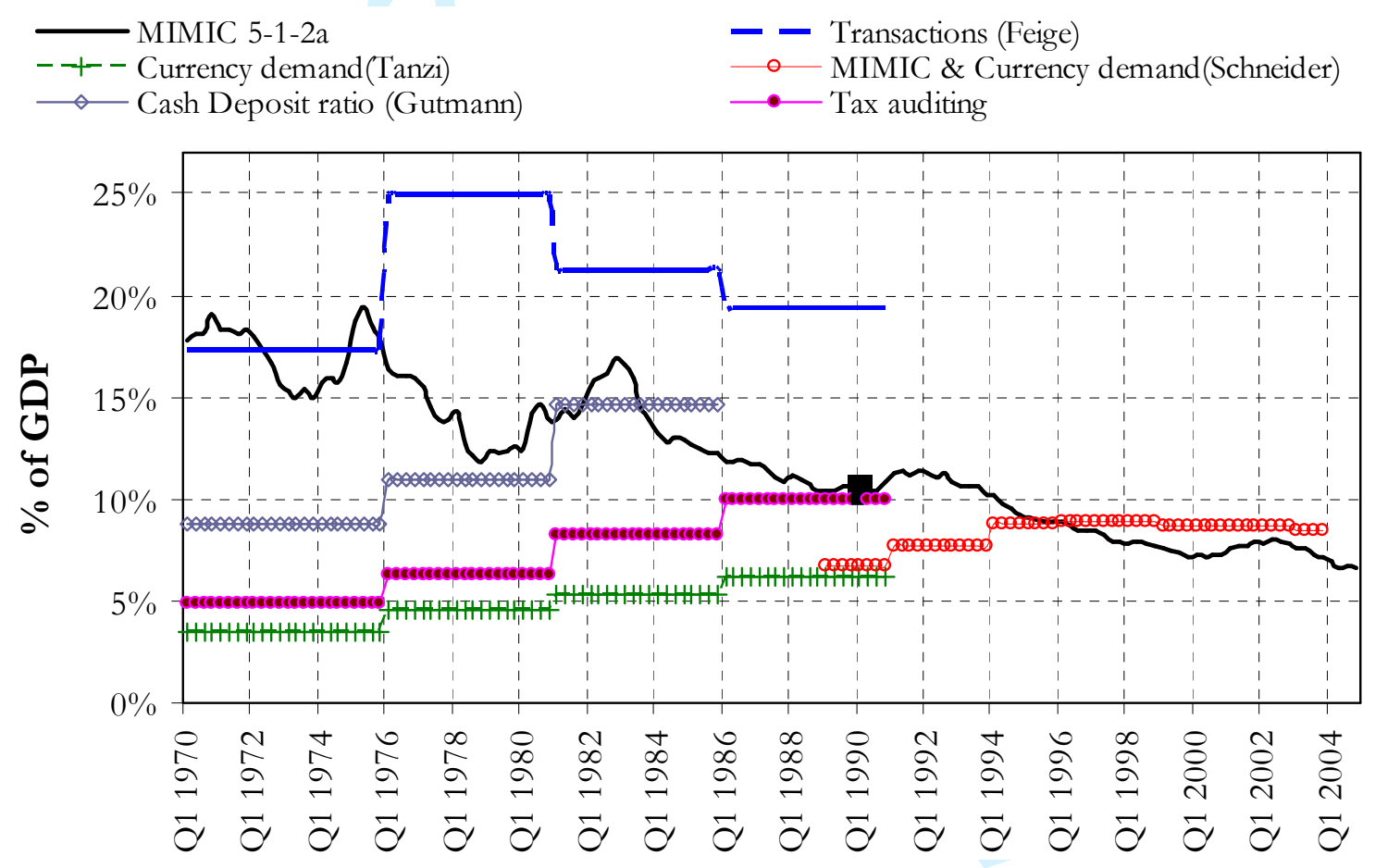

Source: MIMIC 5-1-2a own calculation. The Estimates from 1970 to 1990 are extracted by Schneider, Enste (2000, table 8). Estimates from 1989 to 2003 are extracted by Schneider (2005, table 3.8. The values for 1990-93 are equal to the average of Schneider's estimates for $1989 / 90$ and 1994/95). 
Figure 4: Shadow Economy Vs Unemployment rate

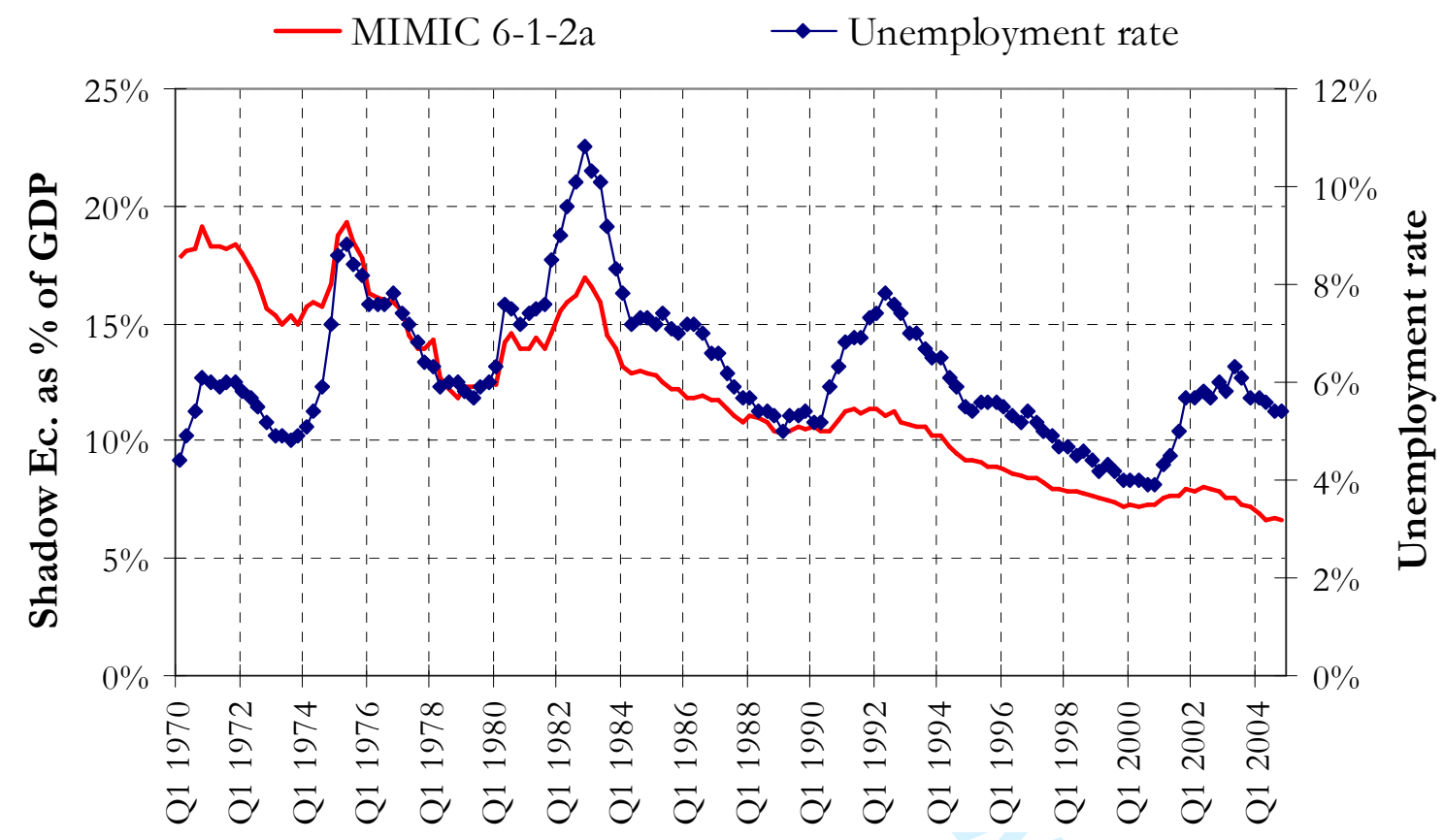


Figure 5: Growth of Official GDP, Changes of Unemployment and Growth of Shadow Economy

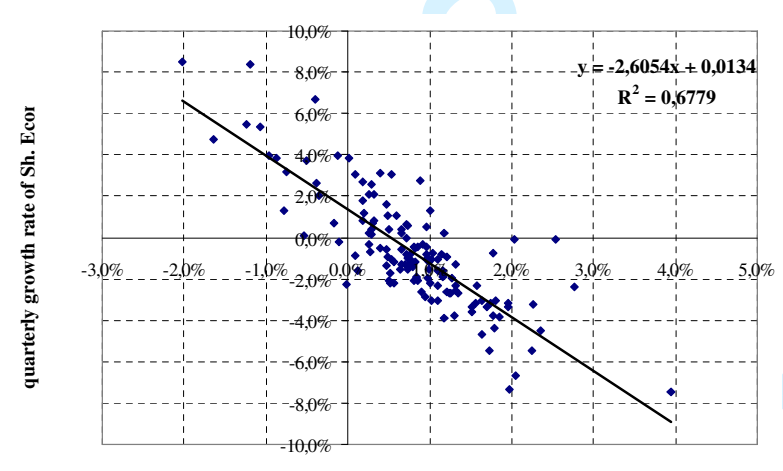

quarterly growth rate of Official GDP

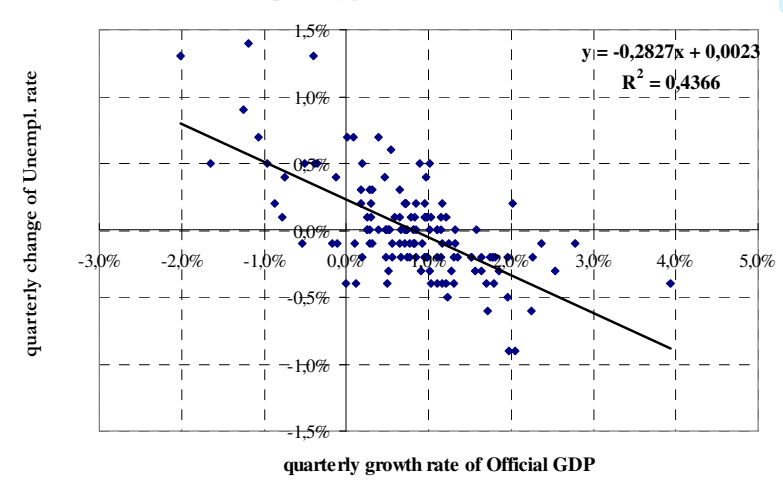

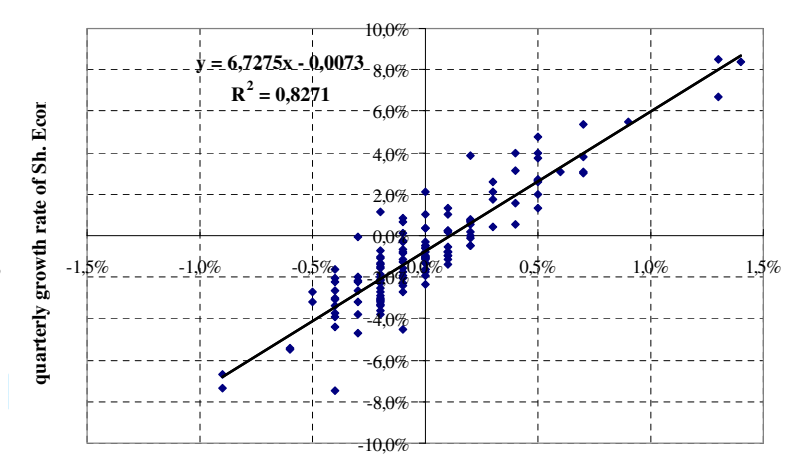

quarterly change of unemployment rate

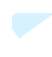

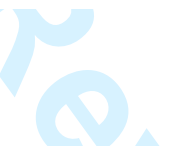


Figure 6: Plots of Variables
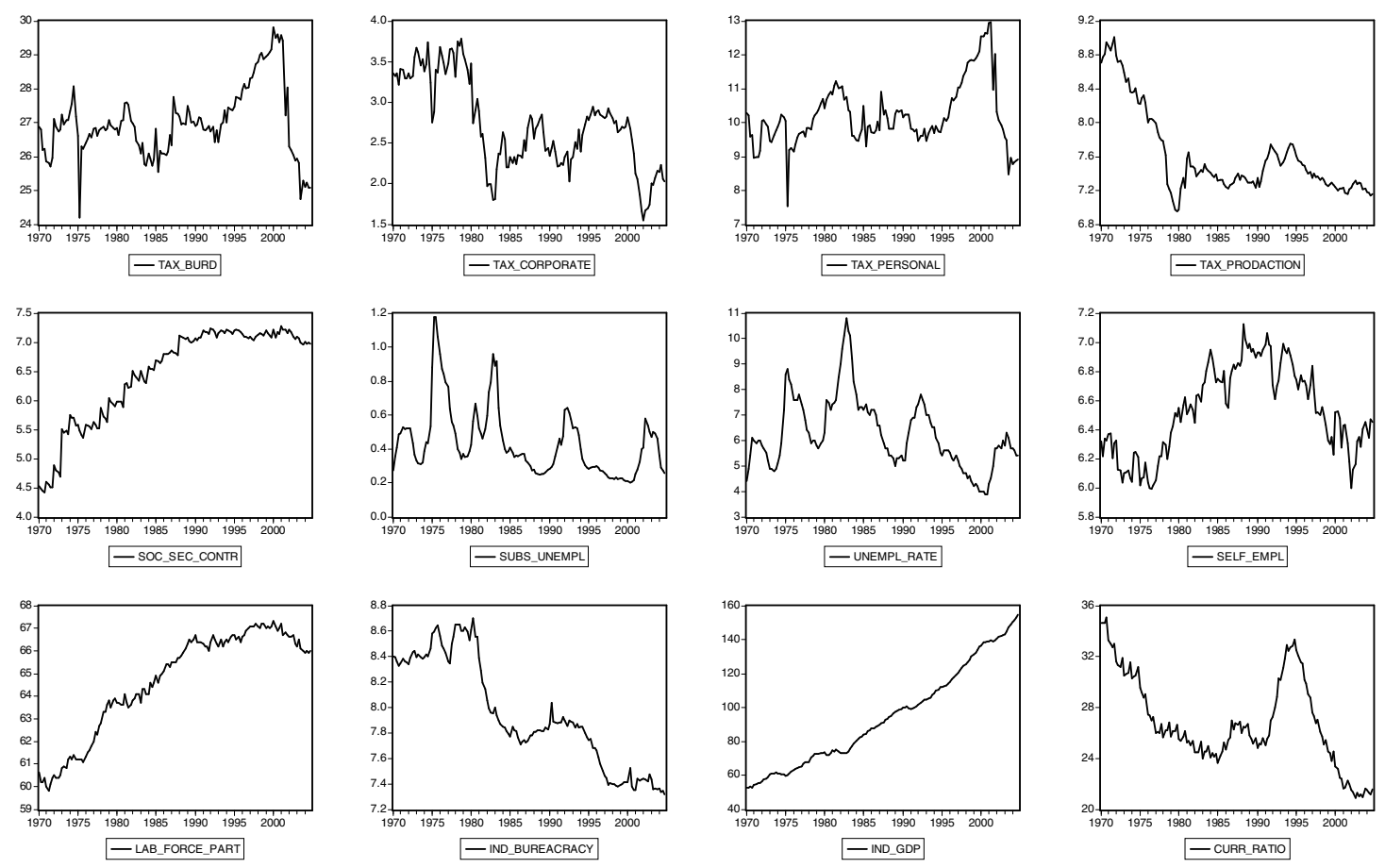